\title{
Effect of organic and mineral fertilization on proximate composition of three leafy vegetables harvested at different periods
}

\author{
Adjouavi Nadia Carole SOSSA-VIHOTOGBE, Bienvenu Victor ANIHOUVI, \\ Houèdougbé Noèl AKISSOE, Lucien Guillaume AMADJI and \\ Djidjoho Joseph HOUNHOUIGAN *
}

\begin{abstract}
Faculté des Sciences Agronomiques, Université d'Abomey-Calavi, 01BP 526 Cotonou, Bénin.
*Corresponding author; E-mail : joseph.hounhouigan@gmail.com, Tel: +229 971414 11, 01 BP 526

Cotonou, Bénin.
\end{abstract}

\begin{abstract}
Leafy vegetables are part of natural resources traditionally harvested from forests in Benin. Some of these wild plants foods have been introduced in the small scale production system. The low productivity and the increasing demand for such products urged to use fertilizers. However, the impact of such practices on the nutritional properties of these leaves was poorly documented. In this study Sesamum radiatum, Ceratotheca sesamoïdes and Justicia tenella were cultivated using NPK, cowpat and mixture of NPK plus cowpat. Leaves harvested at $6,9,10,12$ or 14 weeks after transplanting were analyzed for proximate composition. Protein content ranged from 17.2 to $33.8 \mathrm{~g} / 100 \mathrm{~g} \mathrm{DW}$; ash from 7.7 to $20.4 \mathrm{~g} / 100 \mathrm{~g}$; fat from 1.2 to $7.3 \mathrm{~g} / 100 \mathrm{~g}$, fiber from 5.6 to $13.1 \mathrm{~g} / 100 \mathrm{~g}$ and polyphenols content from 0.24 to $1.33 \mathrm{~g} \mathrm{GAE} / 100 \mathrm{~g}$ (DW). Significant effects of species, fertilizer and cutting time were evidenced. Whereas ash content increased by 1 to $25.8 \%$ ratio in fertilized $S$. radiatum leaves, it showed a downward trend (-1 to $-22 \%)$ during the two first cutting times of $C$. sesamoides followed by an upward trend (12.7 to $14.3 \%)$ at the last cutting time, in comparison to the non fertilized leaves.
\end{abstract}

(c) 2013 International Formulae Group. All rights reserved.

Keywords: Fertilization, composition, Sesamum radiatum, Ceratotheca sesamoides, Justicia tenella

\section{INTRODUCTION}

Leafy vegetables are consumed in many countries in Africa. They are important sources of vitamins ( $\beta$-carotene, ascorbic acid), proteins, dietary fiber and minerals (Akubugwo et al., 2007; Ndong et al., 2007; Afoloyan and Jimoh, 2009) and played a vital role in the improvement of nutritional status of populations (Olaniyi and Ajibola, 2008).

In Benin, a large variety of leafy vegetables are used in daily diet. Among these, Ocimum gratissimum L., Vernonia amygdalina, Amaranthus cruentus, Celosia argentea, Solanum macrocarpon L., Manihot esculenta, Vitex doniana, Corchorus olitorius and Launea taraxacifolia are very popular, and some of them were recently investigated for their nutritional composition (Grefeuille et al., 2010).

Sesamum radiatum, Ceratotheca sesamoides and Justicia tenella are traditional leafy vegetables commonly used in the center 
and the north of Benin to prepare different types of sauces (Dansi et al., 2008; SossaVihotogbé et al., 2012). Some of these leafy vegetables are under domestication (Vodouhè et al., 2011). Therefore, some minimal cultural conditions such as the use of fertilizer are necessary to fulfill their agronomic potential. Gardens usually used organic and mineral fertilizers to enhance yields of common leafy vegetables. Nitrogen is recognized as the most important element in the growth and production of plants (Auwalu et al., 2007). There is a lack of information about nutritional values of traditional leafy vegetables obtained after fertilization although this is of great importance for promoting the use of fertilizer for their cultivation. Some research works showed that carotenes and vitamin B1 contents were enhanced in spinach and tea leaf (Mozafar, 1993). According to Tendonkeng et al. (2010) protein level of Brachiaria ruziziensis was enhanced after nitrogenous fertilization. However, according to Warman and Havard (1996), organic and conventional fertilizers applied to carrot did not affect its vitamins contents. So, there is a need for further research in this field.

The objective of this study was to assess the effect of fertilization and harvesting times on: the proximate composition and total phenolic content of $S$. radiatum (Schumach. \& Thonn.), C. sesamoïdes (Endl.) and J. tenella (Nees T. Anderson), three leafy vegetables consumed in Benin.

\section{MATERIALS AND METHODS}

\section{Study area}

The experiment was conducted from May to November 2008 in two contrasting ecological zones of Benin: the experimental site of the International Institute of Tropical Agriculture (IITA, Benin Branch in the Guineo-Congolese region) and the local farmlands in Savè (the Centre-Benin in the Soudano-Guinean region) (Table 1).

\section{Field experiment}

The experiment was conducted following a randomized complete block design with five replications and two (2) main factors. The first factor (fertilizer) was constituted of four (4) treatments: control (no fertilizer), chemical fertilizer (NPK), organic fertilizer (Cowpat) and mixture of chemical and organic fertilizers (400 kg.ha ${ }^{-1}$ and 20t.ha ${ }^{-1}$ respectively). The NPK used in this study is a combination of urea [CO $\left.\left(\mathrm{NH}_{2}\right)_{2}\right]$ with $36 \%$ of nitrogen, plus tri-super phosphate $\left(\mathrm{P}_{2} \mathrm{O}_{5}\right)$ with $46 \%$ of phosphorus and potassium sulfate $\left(\mathrm{K}_{2} \mathrm{SO}_{4}\right)$ with $50 \%$ of potassium. The second factor was the harvest time $(6,9$ and 12 WAT or 6,10 and 14 WAT). The seeds of $S$. radiatum and J. tenella were collected at Savè and Natitingou and germinated during 30 days in the experimental areas cited above. The experimental units were rectangular plots of $4.5 \times 1.5 \mathrm{~m}$. Four treatments were considered. In the case of $C$. sesamoïdes, the seeds were not germinated, but young plants which grow naturally in the area were just dug up.

The plots were prepared one week before transplanting because of burring of cowpat, potassium sulfate and tri super phosphate at $20 \mathrm{~T}(\mathrm{dwb}), 40 \mathrm{~kg}$ and $80 \mathrm{~kg}$ per hectare respectively. As far as the urea is concerned, it has been applied one week after transplanting and each week during 3 weeks period to avoid losing (Gros, 1979). Thus for inorganic fertilization, TSP, potassium sulfate and urea were used taking into account formulation 10-10-20 at $400 \mathrm{~kg}$ per hectare of NPK. Thirty (30) days after nursery, young plants of $S$. radiatum and $J$. tenella are transplanted. In the case of $C$. sesamoïdes, young plants naturally grown were just transplanted. Plantation density is 16 plants $\mathrm{m}^{-2}$ for $S$. radiatum and J. tenella and 5 plants $\mathrm{m}^{-2}$ for $C$. sesamoïdes. Recommended cultural practices such as watering and eradication of weeds were adopted uniformly according to 
Table 1: Characteristics of the experimental sites in Benin.

\begin{tabular}{|c|c|c|}
\hline Place & IITA, Benin Branch & Local Farmland of Savè, Benin \\
\hline Region of Benin & South & Centre east \\
\hline Geographic location (in decimal degree) & $6.36^{\circ} \mathrm{N} / 2.54^{\circ} \mathrm{E}$ & $7.78^{\circ} \mathrm{N} / 2.28^{\circ} \mathrm{E}$ \\
\hline Annual precipitation (mm / year) & 1200 & 1060 \\
\hline Annual mean temperature $\left({ }^{\circ} \mathrm{C}\right)$ & 27.3 & 27.7 \\
\hline Season during the experiments & Rain season & Rain season \\
\hline Soil types and characteristics & $\begin{array}{c}\text { Claylly tropical ferralitic } \\
\text { soil; moderately well drained, } \\
\text { with } 100 \mathrm{~cm} \text { depth, topsoil } \\
\text { pH:5.6, CEC (Cationic Exchange } \\
\text { Capacity: } 8 \mathrm{cmol} / \mathrm{kg}, 0.86 \% \\
\text { topsoil carbon content }\end{array}$ & $\begin{array}{l}\text { Tropical ferruginous soil, poorly } \\
\text { to moderately drained with } 100 \\
\mathrm{~cm} \text { depth, topsoil } \mathrm{pH}: 6.3, \mathrm{CEC} \\
\text { (Cationic Exchange } \\
\text { Capacity): } 10.3 \mathrm{cmol} / \mathrm{kg}, 0.9 \% \\
\text { topsoil carbon content }\end{array}$ \\
\hline History of the experiment fields & $\begin{array}{c}\text { IITA experiments without } \\
\text { chemical or organic fertilizers the } \\
\text { past } 4 \text { years }\end{array}$ & $\begin{array}{c}\text { Maize, cassava and yam without } \\
\text { chemical or organic fertilizers the } \\
\text { past } 4 \text { years }\end{array}$ \\
\hline
\end{tabular}

Adapted from WorldClim database (http://www.worldclim.org/current) and FAO soil database

(www.fao.org/geonetwork/srv/en/main.home\#), IITA : International Institute of Tropical Agriculture.

standard crop requirements. Moreover, weeds were manually controlled.

\section{Sampling}

Three harvests were realized for each vegetable and began six weeks after transplanting (WAT) from three randomly selected rows per plot. For $S$. radiatum and $J$. tenella, harvest took place at 6, 9 and 12 WAT while the harvest of $C$. sesamoïdes took place at 6,10 and 14 WAT (because of low quantity of leaves of $C$. sesamoïdes observed at 9 WAT). The cutting was realized at $10 \mathrm{~cm}$ of collar of plants. The plants which were located in the border lines and in the end of harvest lines were not considered. After harvesting, the leaves and young shoots were separated from the branches. Edible leaves from $S$. radiatum and $C$. sesamoïdes were just wiped with kitchen towel and J. tenella leaves cleaned with tap water to remove sand and left to drain before making analysis. One part of samples were put in an envelope and dried in oven at $60{ }^{\circ} \mathrm{C}$ and the second part was dried in paper towel before determining dry matter.

\section{Determination of proximate composition}

The dried leaves were ground using a blender (Moulinex). The ground samples were packaged in plastic containers and stored below $4{ }^{\circ} \mathrm{C}$ for analysis. Proximate composition was determined using the recommended methods of AOAC (1995): ash (942.05), crude protein (945.01), crude fiber (962.09) and crude fat (920.39). The moisture content of the samples was determined by drying 3 to $5 \mathrm{~g}$ of fresh sample at $105^{\circ} \mathrm{C}$ in oven during 24 hours.

\section{Total phenolics determination}

Total phenolics compounds (PCs) in the extracts were determined by the modified Folin-Ciocalteu method (Kayode et al., 2007). A sample of $50 \mathrm{mg}$ of dried leaf flour was extracted with $1.5 \mathrm{ml}$ of $\mathrm{HCl} /$ methanol $(1 \% \mathrm{v} / \mathrm{v})$ for $1 \mathrm{~h}$ under continuous stirring at room temperature. The mixture was centrifuged at 7000xg for $10 \mathrm{~min}$ and supernatant was removed. Next the pellet was re-extracted as described above and supernatants were pooled. Three hundred 
(300) $\mu \mathrm{L}$ of extract were mixed with $4.2 \mathrm{ml}$ of distilled water and $0.75 \mathrm{ml}$ of sodium carbonate solution $(20 \% \quad \mathrm{w} / \mathrm{v})$. After incubation for $30 \mathrm{~min}$ the optical density was measured at $760 \mathrm{~nm}$ using a spectrophotometer (Jenway, UV 6715). Blanks were always freshly prepared, in which Folin-Ciocalteu reagent was replaced by water to correct for interfering compounds. Gallic acid (Aldrich Chemical Company, Steinheim, Germany) was used as standard and the results were expressed as $g$ of gallic acid equivalent per 100 grams of sample.

\section{Statistical analysis}

Analysis of variance on repeated measures (Crowder and Hand, 1990) was performed on the data with SAS program (SAS, v 9.2) to test the effect of organic, mineral fertilizers and cutting time on the nutritional values of the leafy vegetable species. The effect of fertilizers used was compared to natural product using Dunnett test (Gouet and Phillipeau, 1992) at 5\% significance level. Principal Components Analysis was used to link fertilized leaves according to their nutritional contents with Statistica program (Statistica, v6).

\section{RESULTS}

\section{Proximate composition of leafy vegetables}

Fertilizer and time of harvest had significant effect $(\mathrm{p}<0.001)$ on moisture, crude protein, total fat, ash, polyphenol and crude fiber content of $S$. radiatum leaves (Table 2). Moreover, the interaction between these factors was also significant (treatment*cutting time).

At 6 WAT, the moisture content of the control was the least whereas that of leaves from NPK was the highest. Irrespective of fertilizer, the moisture content showed an upward trend with cutting time. The mean moisture content of control increased from
71.9 to $81.0 \%$ between 6 and 12 WAT. Except for 6 WAT, the moisture content of leaves fertilized with the cowpat was the highest whatever the harvesting time (Figure 1a).

As far as crude protein is concerned, leaves from plots fertilized by cowpat had an upward trend with cutting time. Apart from cowpat, leaves from other treatments had maximum protein content at 9 WAT, with significantly high value for NPK (Figure $1 \mathrm{~b}$ ).

With regard to total ash (Figure 1c), the control had significantly low total ash content at 6 WAT but a downward trend was noticed whatever the fertilizers applied. In the case of total fat (Figure 1d), fertilized leaves gave lower values than the control samples at 6 WAT. Irrespective of fertilizers, total fat contents of samples decreased from 6 to 9 WAT. As far as crude fiber in $S$. radiatum is concerned (Figure 1e), the control gave the highest value at 6 WAT but the lowest at 9 and 12 WAT whatever the fertilizer.

Regarding C. sesamoïdes, fertilizer and cutting time effects were evidenced, together with their interaction. ( $p<0,001$; Table 3).

The moisture content of leaves obtained from the control was the highest at 6 WAT while that of the cowpat was the lowest. A downward trend was observed for samples from all fertilizers, and the control between 6 and 10 WAT, but invariable thereafter (Figure 2a).

Crude protein content increased from 6 to 14 WAT for all samples, except those from a mixture of organic and mineral fertilization (Figure 2b). Total ash content of samples from NPK fertilization decreased with cutting time. Except for NPK fertilization, total ash content reached minimum value at $10 \mathrm{WAT}$ for all samples together with the control (Figure 2c).

Regarding total fat content, significant difference was evidenced at 6 WAT in fertilized samples, with samples from the 
cowpat giving the lowest value $(p<0.05)$. Irrespective of fertilizer, the fat content was higher at 6 WAT and then showed a downward trend (Figure 2d). In the case of crude fiber (Figure 2e), samples from the mixture of organic and mineral fertilizers (NPK + Cowpat) had significantly higher value at 6 WAT while crude fiber content was higher for the control than fertilized samples at 10 and 14 WAT. Crude fiber content seemed to increase under all fertilizers up to 14 WAT.

As regard to $J$. tenella, the proximate composition was significantly $(\mathrm{p}<0.001)$ affected by fertilizer, harvest time and the interactions of these two factors (Tableau 4). Moisture content in leaves of the control (Figure 3a) was significantly lower $(\mathrm{p}<0.001)$ than that of fertilized samples whatever the harvest time. Then, irrespective of the fertilizers, leaves had minimum moisture content at 9 WAT. In the case of crude protein (Figure 3b) in J. tenella, samples from cowpat gave the significantly lowest values $(\mathrm{p}<0.001)$ at 6 WAT. In addition, crude protein content showed a downward trend after 6 WAT whatever the fertilizer. As for total ash content (Figure 3c), the control showed the significantly lowest values $(\mathrm{p}<0.05)$ while the "NPK + cowpat" showed the highest value at all cutting time; thereafter, minimum values were observed at 9 WAT for all treatments. Regardless of fertilizers, total fat content decreased with cutting time. Then, all the fertilized leaves had higher total fat content than the control at 9 WAT (Figure 3d).

None of treatments was significantly different $(\mathrm{p}>0.05)$ in crude fiber content (Figure 3e) for J. tenella at 6 WAT while they were significantly different at 9 and 12 WAT. Organic treatment together with the control samples showed upward trend for crude fiber content from 6 to 12 WAT. In the case of mineral and mixture of mineral and organic applications, crude fiber content was $\mathrm{r}$ at 12 WAT. It was noticed that, application of fertilizers had different effect in proximate composition of studied leafy vegetables.

\section{Total phenolic contents}

Total phenolic contents in leafy vegetables ranged between 0.24 and $1.33 \mathrm{~g}$ GAE (gallic acid equivalent)/100g. Significant effect of fertilizers on total phenolic contents was evidenced in $S$. radiatum. The use of fertilizers significantly increased $(p<0.05)$ total phenolic contents in leaves after 6 WAT compared with the control. In addition, samples fertilized with NPK and "NPK+Cowpat" reached maximum total phenolic contents at 9 WAT whereas that of samples with cowpat only continued to increase up to 12 WAT (Figure 1f).

Irrespective of fertilizers, total phenol content of samples of $C$. sesamoïdes was significantly higher at 10 and 14 WAT compared with 6 WAT. No general trend could be established with respect to fertilizers. However, NPK and "NPK+Cowpat" had lower total phenol content than the control at 10 and $14 \mathrm{WAT}$; the latter being similar to samples from cowpat fertilizer (Figure 2f).

As for $J$. tenella, fertilizer had significant effect on total phenol content at all cutting time (Figure 3f). Apart from "NPK+Cowpat", samples showed a downward trend for total phenol content, with a minimum at 9 WAT. The concentration of total phenolic compounds in leaves from the mixture of organic and mineral application was almost the same during harvest time.

\section{Relation between nutritional parameters of vegetable leaves from fertilized plots}

Principal Components Analysis (PCA) was performed between nutritional parameters and fertilized vegetable leaves. Referring to the PCA (Figure 4), the two first axes 
compiled $61 \%$ of the total variation in the data set. Considering the nutritional components, moisture, total ash and total polyphenols are positively correlated with axis 1 while crude fiber and total fat are negatively correlated with this axis (Table 5). Only crude protein is positively correlated with axis 2 . Thus, the axis 1 was considered to be that of leaves with high content in moisture, total ash and total polyphenols and low content in total fat and crude fiber while axis 2 was that of the leaves with high content in crude protein.

Hierarchic classification and variables projection on principal components of different leafy vegetables showed 3 groups of leafy vegetables. The first one was constituted of C. sesamoïdes leaves provided from 6 to 14
WAT for all treatments (samples 1 to 12 ), S. radiatum leaves provided from organic, mineral and the mixture of organic and mineral fertilization at 6 WAT (14 to 16) and J. tenella leaves provided at $6 \mathrm{WAT}$ for all treatments and for control, and for organic and mineral fertilization at 9 and 12 WAT (25 to 31 and 33 to 35). These leaves were characterized by a high level of moisture, total ash and total phenolic compounds. The leaves of $S$. radiatum at 9 and 12 WAT for all treatments (17 to 24) (group 2) were associated with high level of crude protein. Only $S$. radiatum leaves obtained for the control at 6 WAT was associated with low level of crude fiber and total fat.

Table 2: F values and significance of nutritional values of Sesamum radiatum for different treatments and cutting times.

\begin{tabular}{lccccccc}
\hline Source & df & Moisture & Total Ash & $\begin{array}{c}\text { Crude } \\
\text { Fiber }\end{array}$ & Total Fat & $\begin{array}{c}\text { Crude } \\
\text { Protein }\end{array}$ & $\begin{array}{c}\text { Phenolic } \\
\text { compounds }\end{array}$ \\
\cline { 2 - 7 } & & & \multicolumn{7}{c}{ F values } \\
\hline Treat & 3 & $652.30 * * *$ & $156.61 * * *$ & $0.84 \mathrm{~ns}$ & $504.4 * * *$ & $61.41 * * *$ & $13.03 \mathrm{~ns}$ \\
Plot & 2 & $1693.39 * * *$ & $236.58 * * *$ & $141.58 * * *$ & $438.64 * * *$ & $964.54 * * *$ & $116.36 * * *$ \\
Treat*plot & 6 & $1526.46 * * *$ & $54.39 * * *$ & $47.14 * * *$ & $102.57 * * *$ & $206.98 * * *$ & $19.49 * * *$ \\
Time & 2 & $12105.3 * * *$ & $1526.76 * * *$ & $307.08 * * *$ & $3059.42 * * *$ & $26763.1 * * *$ & $41.63 * * *$ \\
Time*treat & 6 & $312.50 * * *$ & $61.14 * * *$ & $211.91 * * *$ & $484.58 * * *$ & $132.77 * * *$ & $7.45 \mathrm{~ns}$ \\
Time*plot & 4 & $722.97 * * *$ & $83.61 * * *$ & $37.79 * * *$ & $41.39 * * *$ & $655.84 * * *$ & $25.71 * * *$ \\
Time*treat*plot & 12 & $1005.88 * * *$ & $25.84 * * *$ & $61.17 * * *$ & $46.83 * * *$ & $64.78 * * *$ & $4.16 \mathrm{~ns}$ \\
\hline
\end{tabular}

$d f$ : degree of freedom, $F$ : Fisher, $* * *$ Significant at $0.001, n s$ : not significant. 
Table 3: $\mathrm{F}$ values and significance of nutritional values of Ceratotheca sesamoïdes for different treatments and cutting times.

\begin{tabular}{|c|c|c|c|c|c|c|c|}
\hline \multirow[t]{2}{*}{ Source } & df & Moisture & Total Ash & $\begin{array}{l}\text { Crude } \\
\text { Fiber }\end{array}$ & Total Fat & $\begin{array}{l}\text { Crude } \\
\text { Protein }\end{array}$ & $\begin{array}{l}\text { Phenolic } \\
\text { compounds }\end{array}$ \\
\hline & & \multicolumn{6}{|c|}{ F values } \\
\hline Treat & 3 & $248.33^{* * *}$ & $394.35^{* * *}$ & $26.64 * * *$ & $71.51 * * *$ & $314.84^{* * *}$ & $3975.39 * * *$ \\
\hline Plot & 2 & $674.25 * * *$ & $447.02 * * *$ & $12.91 * * *$ & $75.54 * * *$ & $798.60 * * *$ & $589.16^{* * *}$ \\
\hline Treat*plot & 6 & $200.14 * * *$ & $10.41 \mathrm{~ns}$ & $15.46^{* * *}$ & $14.15 * * *$ & $320.35 * * *$ & $138.12 * * *$ \\
\hline Time & 2 & $1556.10 * * *$ & $1493.66 * * *$ & $369.41 * * *$ & $461.84 * * *$ & $1509.48 * * *$ & $30804.4 * * *$ \\
\hline Time*treat & 6 & $287.47 * * *$ & $272.84 * * *$ & $46.77 * * *$ & $25.81 * * *$ & $106.38 * * *$ & $1510.11 * * *$ \\
\hline Time*plot & 4 & $1037.81 * * *$ & $54.75 * * *$ & $19.59 * * *$ & $62.58 * * *$ & $203.24 * * *$ & $47.58 * * *$ \\
\hline Time*treat*plot & 12 & $214.45^{* * *}$ & $115.44 * * *$ & $15.64 * * *$ & $22.06 * * *$ & $165.02 * * * *$ & $66.33 * * *$ \\
\hline
\end{tabular}
df: degree of freedom, $F$ : Fisher, $* * *$ Significant at $0.001, n s$ : not significant.

Table 4: $\mathrm{F}$ values and significance of Justicia tenella for different treatments and cutting times.

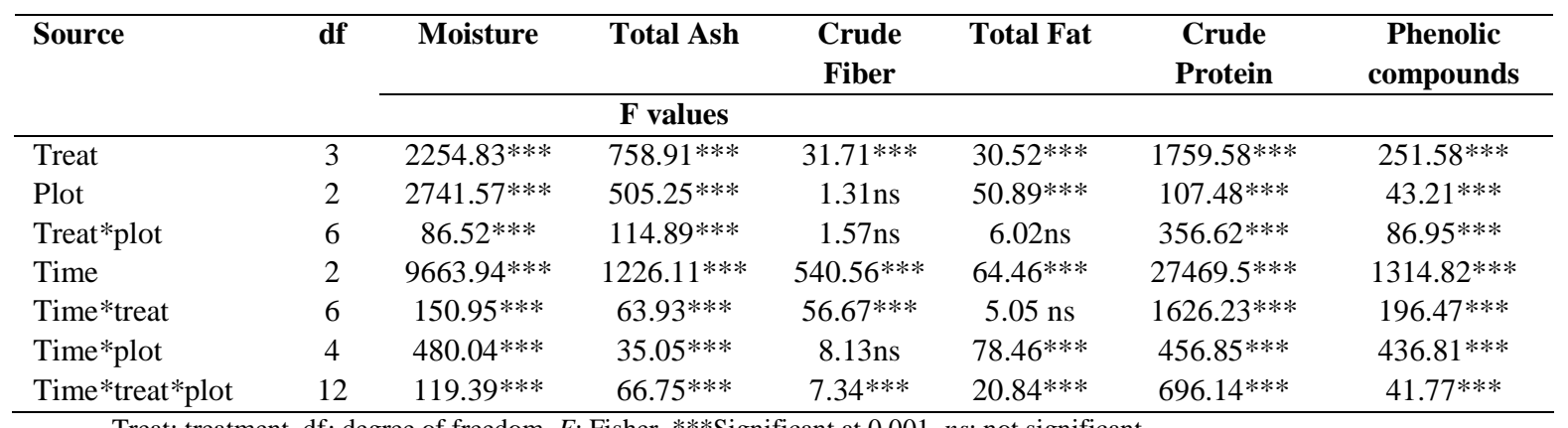

Treat: treatment, df: degree of freedom, $F$ : Fisher, ${ }^{* * *}$ Significant at $0.001, n s:$ not significant.

Table 5: Correlation between principal components and variables.

\begin{tabular}{lcc}
\hline Variables & Axis 1 & Axis 2 \\
\hline Moisture & 0.68 & 0.09 \\
Crude protein & 0.09 & 0.81 \\
Total fat & -0.65 & -0.4 \\
Total ash & 0.68 & -0.64 \\
Crude fiber & -0.76 & -0.28 \\
Total phenolic contents & 0.55 & -0.33 \\
\hline
\end{tabular}



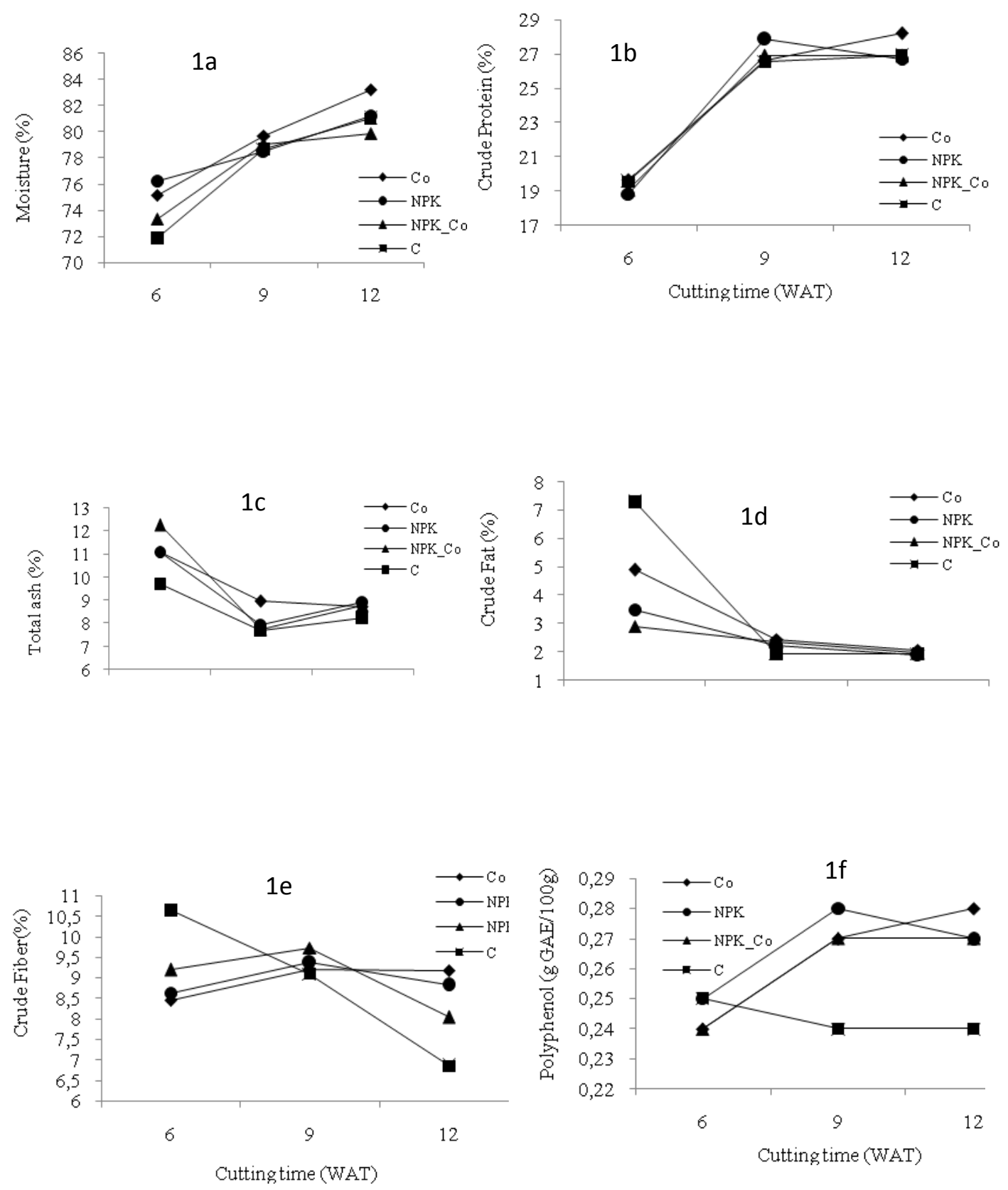

Figure 1: Proximate composition of Sesamum radiatum at different treatments and cutting time. C: control; Co: cowpat; NPK_Co: NPK + cowpat. 

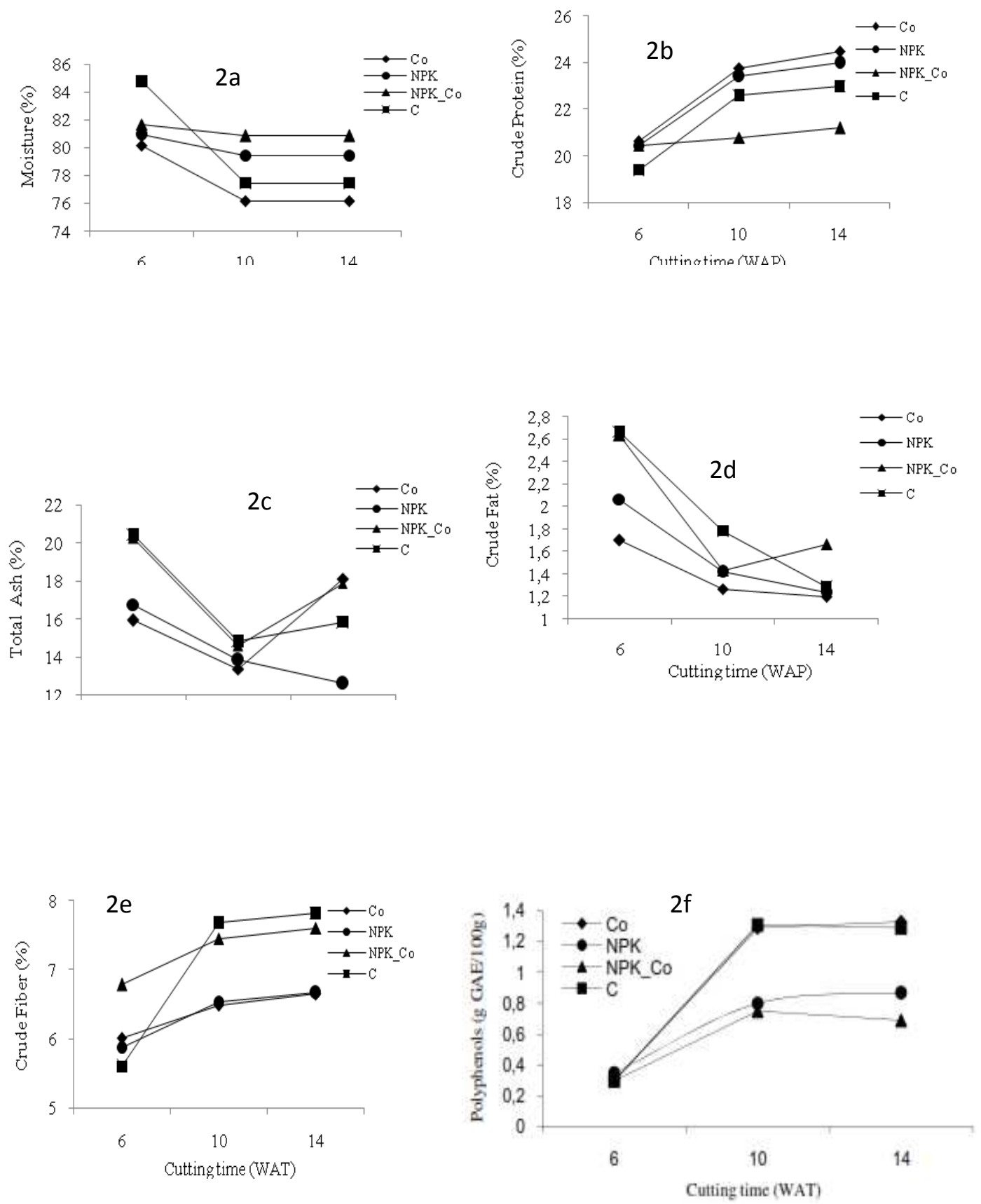

Figure 2: Proximate composition of Cerathoteca sesamoïdes at different treatments and cutting times. C: control; Co: cowpat; NPK_Co: NPK + cowpat. 

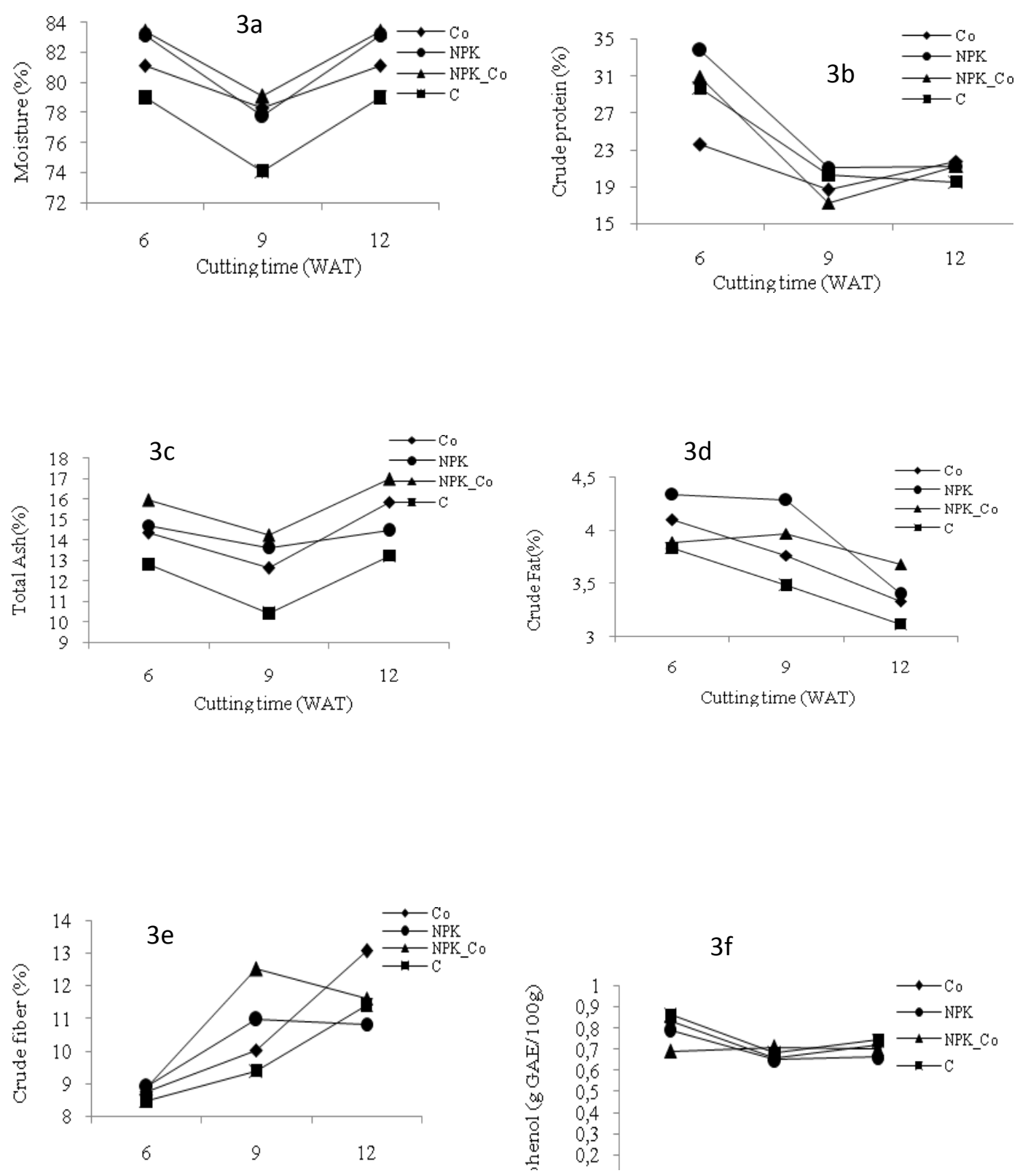

Figure 3: Proximate composition of Justicia tenella at different treatments and cutting times. C: control; Co: cowpat; NPK_Co: NPK + cowpat 


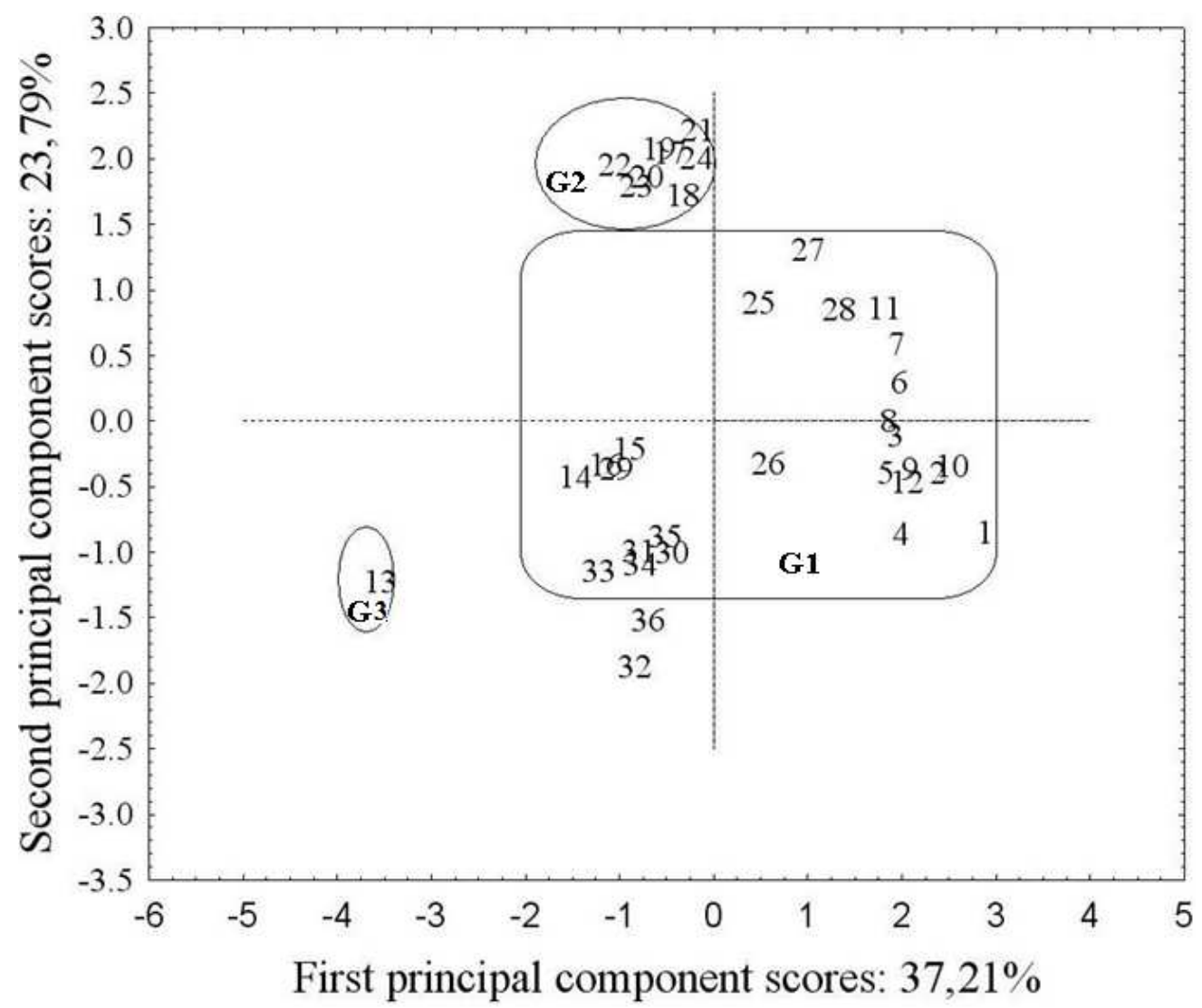

Figure 4: Principal components analysis performed on nutritional characteristics and different types of leaves of $S$. radiatum, C. sesamoïdes and J. Tenella. 1,2,3,4: Ceratotheca sesamoïdes (C. sesamoïdes) leaves after 6 WAT (control, cowpat, NPK, NPK+ cowpat); 5,6,7,8: C. sesamoïdes leaves after 10 WAT (control, cowpat, NPK, NPK+ cowpat); 9,10,11,12: C. sesamoïdes leaves after 14 WAT (control, cowpat, NPK, NPK+ cowpat); 13,14,15,16: Sesamum radiatum (S. radiatum) leaves 6 WAT (control, cowpat, NPK, NPK+ cowpat); 17,18,19,20: Sesamum radiatum ( $S$. radiatum) leaves after 9 WAT (control, cowpat, NPK, NPK+ cowpat); 21,22,23,24: Sesamum radiatum (S. radiatum) leaves after 12 WAT (control, cowpat, NPK, NPK+ cowpat); 25,26,27,28: Justicia tenella (J. tenella) leaves after 6 WAT (control, cowpat, NPK, NPK+ cowpat); 29,30,31,32: Justicia tenella (J. tenella) leaves after 9 WAT (control, cowpat, NPK, NPK+ cowpat); 33,34,35,36: Justicia tenella (J. tenella) leaves after 12 WAT (control, cowpat, NPK, NPK+ cowpat).

\section{DISCUSSION}

\section{Proximate composition of leafy vegetables}

The range of moisture content was 72 to $83.25 \%$ for $S$. radiatum, 77.5 to $81 \%$ for $C$. sesamoïdes and 74 to $83 \%$ for J. tenella. The significant effect of fertilizer on moisture content of S. radiatum, $C$. sesamoïdes and $J$. tenella, is in agreement with those found by Lairon et al. (1983) who reported that application of organic and mineral nitrogen fertilization had significant effect on dry matter content of lettuce. The opposite trend of moisture content observed for species were already reported when organic fertilizer is applied. The high dry matter content (low moisture) obtained for organic fertilization (cowpat) in the case of $C$. sesamoïdes and $J$. tenella were also observed for carrot and cabbage (Pihter and Hall, 1990). On contrary, the high moisture content (low dry matter) of 
S. radiatum leaves at every cutting time was explained by the slow release of nutrients by organic fertilizers (Makinde and Ayoola, 2010).

All the leaves had high level of crude protein ranging between $18.8-27.8 \%$ dwb for $S$. radiatum, $19.4-24.5 \% \mathrm{dwb}$ for $C$. sesamoïdes and 17.2-33.8\% dwb for J. tenella compared with those reported for Struchium spaganophora (7.2\% dwb, Oboh, 2006), Solanum nigrum L (13\%, dwb, Afoloyan and Jimoh, 2008), Sonchus asper (L.) Hill (18.75\%) and Corchorus tridens (15.7-17.7\% dwb), (Asigbe-Berko et al., 1999; Mepha et al., 2007). Regarding fertilizer effect, the high level in crude protein observed during all cutting times for the leaves treated with NPK was expected and this could be mainly explained by the provision of fertilizer nitrogen with fast release (Makinde and Ayoola, 2010). Thus, the amounts of crude protein (19.4-24.46\% dwb) in our study for $C$. sesamoïdes were lower than those obtained (26.08-34.64\% dwb) by Fasakin (2004). Regarding protein, Food and Nutrition Board (2001) mentioned that all food plant that provides more than $12 \%$ of its calorific value from protein is a good source of protein. In the case of our study, all the leaves of $C$. sesamoïdes, S. radiatum and J. tenella had calorific value from protein ranged from 13.45 to $26.8 \%$. In this respect, these leaves can be considered as a good source of protein.

As far as total ash and total fat are concerned, the decrease observed at 9 WAT for S. radiatum, $J$. tenella and 10 WAT for $C$. sesamoïdes was in agreement with Fasakin (2004) who reported that fat and ash contents were higher at week 7 than at week 8, 9 and 10. This situation could be explained by the transfer of nutrients from leaves to the reproductive organs during flowering and fruiting (Hewitt and Marruh, 1986). In the case of S. radiatum and J. tenella, flowering beginning was observed at 7 WAT and 14 WAT respectively while it was observed at 8 WAT for $C$. sesamoïdes. However, no significant difference $(\mathrm{p}>0.05)$ was evidenced between ash level for organic and mineral fertilization, as previously observed by Shier et al. (1984) and Evers (1989). As well, total ash contents in C. sesamö̈des (12.61-20.43\% $\mathrm{dwb}$ ) were higher than the amounts of total ash in S. radiatum (7.7-12.26\% dwb) and $J$. tenella (10.4-16.96\% dwb). Accordingly, the discrepancy in ash contents was reported by several works (Fasakin, 2004; Fasuyi, 2007): the low levels were obtained for $C$. sesamoïdes cultivar (8.8-13\%) consumed in Nigeria (Fasakin, 2004) and Vernonia species (7.72-11.96\% dwb) (Ejoh et al., 2007) whereas those reported by Fasuyi (2007) for Talinum triangulare and Amaranthus cruentus were higher (19.3-19.4\% dwb). Total fat content varied with species, fertilizer and harvest time, ranging between $1.2 \mathrm{~g} / 100 \mathrm{~g}$ $\mathrm{dwb}$ and $7.28 \mathrm{~g} / 100 \mathrm{~g}$ dwb. These values were comparable with the results of many authors who found low total fat contents in leafy vegetables (Asigbe-Berko et al., 1999; Fasakin, 2004; Fasuyi, 2007; Akubugwo, 2007; Ejoh et al., 2007; Flyman et al., 2007; Afoloyan et Jimoh, 2008; Taiga et al., 2008; Aberoumand, 2009).

A high variability in the crude fiber contents of leaves was also reported. The crude fiber content in $C$. sesamoides leaves (5.6-7.81\% dwb) is comparable to those obtained at 7 WAP and 8 WAP (Fasakin, 2004) but lower than those of leafy vegetables consumed in Ghana (Asigbe-Berko et al., 1999) and in Telfairia occidentalis (19.57\% dwb) (Taiga et al., 2008), Talinum triangulare (11.9\%, dwb, Fasuyi, 2007). In the case of $S$. radiatum (6.85-10.65\% dwb) and J. tenella (8.7-13.05\% dwb), their crude fiber content 
are similar to some of leafy vegetables consumed in Botswana, Nigeria, Ghana and Iran (Asigbe-Berko et al., 1999; Fasuyi, 2007; Akubugwo, 2007; Ejoh et al., 2007; Flyman et al., 2007; Taiga et al., 2008; Aberoumand, 2009). Dietary fiber in leafy vegetable contributed in regulation of intestinal transit, increase dietary bulk and faeces consistency due to their ability to absorb water (Jenkin et al., 1986).

\section{Total polyphenolic content}

The high variability observed in total polyphenolic content during harvest could be attributed to variation of metabolic activities in the plants in relation with fertilizer effects. Liu et al. (2010) showed that the variation of phenolic compounds in pigeon pea leaves correlates with the metabolic balance of plants and external environmental disturbance. Phenolic content in $S$. radiatum leaves at every harvest time and for all treatments ranged between 240-280 mg GAE/100 g dwb. These values were higher than phenolic content in Vigna unguiculata (130 mg GAE /100 g dwb), Amaranthus hybridus L. (0.35 mg GAE/100 g dwb), Vernonia species (4.37$9.75 \mathrm{mg}$ GAE/100 $\mathrm{g} \mathrm{dwb}$ ) and others leafy vegetables consumed in South Africa, but comparable with that of Talinum triangulare (230 mg GAE /100 g dwb) (Tchiegang and Kitikil, 2004; Akubugwo et al., 2007; Ejoh et al., 2007). Reversely, phenolic content of $S$. radiatum was lower than those of Corchorus olitorius (970 mg GAE /100 g dwb), Hibiscus sabdariffa (780 mg GAE /100 g dwb) (Tchiegang and Kitikil, 2004; Akubugwo et al., 2007; Ejoh et al., 2007; Afoloyan and Jimoh, 2008). In the case of $C$. sesamoïdes and $J$. tenella, the range of $0.3-1.33 \mathrm{~g} \mathrm{GAE}$ $/ 100 \mathrm{~g}(\mathrm{dwb})$ and 0.66-0.86 g GAE/100 $\mathrm{g}$ (dwb) respectively were consistent with the mean value (0.8 g GAE $100 \mathrm{~g} \mathrm{dwb}$ ) reported by Tchiegang and Kitikil (2004) on $C$. sesamoïdes. The high level of phenolic compounds in leafy vegetables could impact food nutritional value. Indeed, polyphenols in fruits, vegetables and herbs appear to be responsible at least partly, for many of reported protective effects against a variety of diseases, including cancer and cardiovascular diseases (Moskaug et al., 2005). Reversely, polyphenols inhibit non-haem-Fe absorption, reduce thiamin absorption, reduce digestibility of starch, protein and lipids and interfere with protein digestibility (Bravo, 1998).

\section{Mapping of fertilized leaves of $S$. radiatum, C. sesamoüdes and J. tenella}

The fertilized leaves were classified into three categories of leaves according to their nutritional value. The first group is composed of leaves of $C$. sesamoïdes obtained for all fertilizer treatments at all harvest time, leaves of $S$. radiatum except for the control at 6 WAT and leaves of J. tenella for all fertilizer treatments at $6 \mathrm{WAT}$ and 12 WAT except for the mixture of organic and mineral treatment (group 1). This group had high level of total ash and polyphenols. The second group is composed of the leaves of $S$. radiatum at 9 and 12 WAT for all treatments. In the same way, the consumption of leaves of group 2, could contribute to provide high level of protein (between 26.54 and $28.19 \mathrm{~g} / 100 \mathrm{~g}$ $\mathrm{dwb})$. The third group is concerned with $S$. radiatum at 6 WAT, with low level of crude fiber and total fat content. The mapping of leafy vegetables indicated that the leaves of group 1 and 2 could provide ash and protein and may be consumed to fight against mineral and protein deficit problem respectively.

\section{Conclusion}

Organic, mineral and mixture of organic and mineral fertilizers had significant 
effect on proximate composition of $S$. radiatum, C. sesamoïdes and $J$. tenella, depending on harvest time and species. In general, the leafy vegetables under study contain high level of protein, crude fiber, polyphenolic compounds and total ash, and low level of total fat. They can contribute significantly to the nutrient requirement of human and be used to supplement other sources of nutrients. Leafy vegetables are consumed after different processing such as drying, blanching and cooking. It will be interesting to evaluate the biological changes of their nutrient content during processing. In this way, the bioavailability of minerals, especially $\mathrm{Fe}$ and $\mathrm{Ca}$ and the effects of processing on their nutritive value should be assessed.

\section{ACKNOWLEDGEMENTS}

This research was sponsored by the scientific council of the University of Abomey-Calavi (UAC) through the collaborative project "6 AVG" on Traditional Leafy Vegetables. We are grateful to Prof. R. Glèlè Kakaï for the statistical analysis.

\section{REFERENCES}

Aberoumand A. 2009. Nutritional evaluation of edible Portulaca oleracia as plant food. Food Anal. Meth., 2: 204-207.

Afolayan AJ, Jimoh FO. 2009. Nutritional quality of some wild leafy vegetables in South Africa. Int. J. Food Sci. Nutr., 60(5): 424-431.

Akubugwo IE, Obasi NA, Chinyere GC, Ugbogu AE. 2007. Nutritional and chemical value of Amaranthus hybridus L. leaves from Afikpo, Nigeria. Afr. J. Biotechnol., 6(24): 2833-2839.

Assigbé-Berko E, Tayi KAF. 1999. Proximate analysis of some under-utilized
Ghanaian vegetables. Ghana. J. Sci., 39: 91-96.

Auwalu BM, Babatunde FE, Oseni TO, Muhammad YM. 2007. Productivity of vegetable sesamum (Sesamun radiatum, Shum) as influenced by nitrogen, phosphorus and season. Adv. Hort. Sci., 21(1): 9-13.

Bravo L. 1998. Polyphenols: chemistry, dietary sources, metabolism, and nutritional significance. Nutr. Rev., 56: 317-333.

Crowder MJ, Hand DJ. 1990. Analysis of repeated Measures. Chapman and Hall: New York; 59.

Dansi A, Adjatin A, Adoukonou-Sagbadja H, Falade V, Yedomonhan H, Odou D, Dossou B. 2008. Traditional leafy vegetables and their use in the Benin Republic. Genet. Resour. Crop Ev., 55: 1239-1256.

Ejoh AR, Djuikwo VN, Gouado I, Mbofoung CM. 2007. Nutritional components of some non-conventional leafy vegetables consumed in Cameroon. Pakistan J. Nutr., 6(6): 712-717.

Evers AM. 1989. Effects of different fertilization practices on the $\mathrm{NO}_{3}-\mathrm{N}, \mathrm{N}$, $\mathrm{P}, \mathrm{K}, \mathrm{Ca}, \mathrm{Mg}$, ash and dietary fibre contents of carrot. J. Agric. Sci., 61: 99111.

Fasakin K. 2004. Proximate composition of bungu (Ceratotheca sesamoides Endl.) leaves and seeds. Biokem., 16(2): 88-92.

Food and Nutrition Board. 2001. Dietary Reference Intake: Elements. Institute of Medicine. National Academy of Sciences: Washington, D.C.

Gibson SR, Perlas L, Hotz C. 2006. Improving the bioavailability of nutrients in plant foods at the household level. Proc. Nutr. Soc., 65: 160-168. 
Gouet JP, Philippeau G. 1992. Comment interpreter les resultats d'une ANOVA. ITCF-ISBN 2-86492-160-X, p. 47.

Greffeuille V, Icard-Vernière C, Avallone S, Fatoumata H, Amoussa W, MouquetRivier C. 2010. Report on the nutritional quality of dishes the most frequently eaten by children in Benin and Burkina Faso: cereal-based dishes, related sauces and raw leafy vegetables, p. 17.

Hewitt JD, Marrush M. 1986. Remobilization of Nonstructural Carbohydrates from vegetative tissues to fruits in tomato. $J$. Am. Soc. Hortic. Sci., 111: 142-145.

Kayodé APP, Linnemann AR, Nout MJR, Van Boekel MAJS. 2007. Impact of sorghum processing on phytate, phenolic compounds and in vitro solubility of iron and zinc in thick porridges. J. Sci. Food Agric., 87: 832-838.

Lairon D, Spitz N, Termine E, Ribaud P, Lafont H, Hauton J. 1984. Effect of organic and mineral nitrogen fertilization on yield and nutritive value of butterhead lettuce. Qual. Plant.- Plant Food Hum. Nutr., 34: 97-108.

Liu W, Zu Y, Fu Y, Kong Y, Mac W, Yang M, Li J, Wua N. 2010. Variation in contents of phenolic compounds during growth and post-harvest storage of pigeon pea seedlings. Food Chem., 121: 732-739.

Makinde EA, Ayoola OT. 2010. Growth, yield and NPK uptake by maize with complementary organic and inorganic fertilizers. Afr. J. Food Agric. Nutr. Develop., 10(3): 2203-2217.

Mepha HD, Eboh L, Banigo DEB. 2007. Effects of processing treatments on the nutritive composition and consumer acceptance of some Nigerian edible leafy vegetables. Afr. J. Food Agric. Nutr. Develop., 7(1): 1-18.
Moskaug JO, Carlsen H, Myhrstad MC, Blomhoff R. 2005. Polyphenols and glutathione synthesis regulation. Am. J. Clin. Nutr., 81(1 Suppl): 277-283.

Mozafar A. 1993. Nitrogen fertilizers and the amount of vitamins in plants: A review, J. Plant Nutr., 16(12): 2479 -2506.

Ndong M, Wade S, Dossou N, Guiro AT, Diagne Gning R. 2007. Valeur nutritionnelle du Moringa oleifera, étude de la biodisponibilité du fer, effet de l'enrichissement de divers plats traditionnels sénégalais avec la poudre des feuilles. Afr. J. Food Agr. Nutr. Develop., 7(3): 1-17.

Oboh G. 2006. Nutritive value, antioxidant and antimicrobial properties of Struchium sparganophora leave. J. M. Food., 9(2): 276-280.

Olaniyi JO, Ajibola AT. 2008. Growth and Yield Performance of Corchorus olitorius Varieties as Affected by Nitrogen and Phosphorus Fertilizers Application. Am.-Eurasian J. Sustain. Agric., 2(3): 234-241.

Olson JA. 1999. Carotenoids and human nutrition. Zrch. Latinoamer Nutr., 49: 75-115.

Pither R, Hall MN. 1990. Analytical Survey of the Nutritional Composition of Organically Grown Fruit and Vegetables, $\quad \mathrm{N}^{\circ} 597$ of Technical Memorandum. Campden Food and Drink Research Association; 32 p.

Shier NW, Kelman J, Dunson JW. 1984. A comparison of crude protein, moisture, ash and crop yield between organic and conventionally grown wheat, Nutr. Rep. Int., 30: 71-76.

Sossa-Vihotogbe CNA, Akissoe NH, Anihouvi BV, Ahohuendo BC, Ahanchede A, Sanni A, Hounhouigan JD. 2012. Endogenous knowledge on 
four leafy vegetables used by rural populations in Benin. Ecol. Food Nutr., 51(1): 22-39.

Taiga A, Suleiman NM, Aina OD, Sule FW, Alege OG. 2008. Proximate analysis of some dry season vegetables in Anyigba, kogi state, Nigeria. Afr. J. Biotechnol., 7(10): 1588-1590.

Tchiégang C, Kitikil A. 2004. Données ethnonutritionnelles et caractéristiques physico-chimiques des legumes-feuilles consommés dans la savane de l'Adamaoua (Cameroun). Tropicultura, 22(1): 11-18.

Tendonkeng F, Boukila B, Pamo TE, Mboko V A, Tchoumboué J. 2010. Effet de différents niveaux de fertilisation azotée sur le rendement et la composition chimique de Brachiaria ruziziensis à la montaison dans l'Ouest Cameroun. Livest. Res. Rural Develop., 22(1): 1-9.

Vodouhè R, Dansi A, Avohou HT, Kpèki B, Azihou F. 2011. Plant domestication and its contributions to in situ conservation of genetic resources in Benin. Int. J. Biodvers. Conserv., 3(2): 40-56.

Warman PR, Havard KA. 1997. Yield, vitamin and mineral contents of organically and conventionally grown carrots and cabbage. Agr. Ecosyst. Environ., 61: 55-162. 